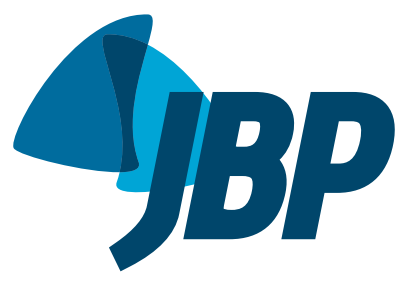

\title{
Determining respiratory system resistance and reactance by impulse oscillometry in obese individuals
}

\author{
Cláudio Gonçalves de Albuquerque1, Flávio Maciel Dias de Andrade1, \\ Marcus Aurélio de Almeida Rocha', Alina Farias França de Oliveira', \\ Waldemar Ladosky ${ }^{1}$, Edgar Guimarães Victor ${ }^{1}$, José Ângelo Rizzo ${ }^{1}$
}

1. Universidade Federal de Pernambuco, Recife (PE) Brasil.

Submitted: 16 December 2014 Accepted: 14 July 2015

Study carried out at the Universidade Federal de Pernambuco, Recife (PE) Brasil.

\begin{abstract}
Objective: To evaluate peripheral respiratory system resistance and reactance (Rrs and Xrs, respectively) in obese individuals. Methods: We recruited 99 individuals, dividing them into four groups by body mass index (BMI): $<30.0 \mathrm{~kg} / \mathrm{m}^{2}$ (control, $\mathrm{n}=31$ ); 30.0 $39.9 \mathrm{~kg} / \mathrm{m}^{2}$ (obesity, $\mathrm{n}=13$ ); $40.0-49.9 \mathrm{~kg} / \mathrm{m}^{2}$ (severe obesity, $\mathrm{n}=28$ ); and $\geq 50.0 \mathrm{~kg}$ / $\mathrm{m}^{2}$ (morbid obesity, $\mathrm{n}=13$ ). Using impulse oscillometry, we measured total Rrs, central Rrs, and Xrs. Peripheral Rrs was calculated as the difference between total Rrs and central Rrs. All subjects also underwent spirometry. Results: Of the 99 individuals recruited, 14 were excluded because they failed to perform forced expiratory maneuvers correctly during spirometry. The individuals in the severe obesity and morbid obesity groups showed higher peripheral Rrs and lower Xrs in comparison with those in the two other groups. Conclusions: Having a BMI $\geq 40 \mathrm{~kg} / \mathrm{m}^{2}$ was associated with a significant increase in peripheral Rrs and with a decrease in Xrs.
\end{abstract}

Keywords: Obesity; Airway obstruction; Oscillometry; Respiratory function tests.

\section{INTRODUCTION}

Obesity currently poses a major risk to human health, affecting more than 600 million people worldwide ${ }^{(1)}$ and constituting a predisposing factor for other health problems, including respiratory diseases, cardiovascular diseases, osteoarticular diseases, diabetes, and hyperlipidemia. ${ }^{(2)}$

Thoracic and abdominal adipose tissue accumulation results in reduced respiratory system compliance and, consequently, increased respiratory effort. In addition, reduced expiratory reserve volume (ERV) and functional residual capacity result in a decrease in lung elastic recoil pressure. The aforementioned factors can play a role in reducing peripheral airway caliber and increasing respiratory system resistance ( $R r s)$ in obese individuals. ${ }^{(3-6)}$ In addition, increased circulating leptin levels are associated with reduced airway caliber and predispose to increased bronchial hyperresponsiveness. ${ }^{(7,8)}$

A variant of the forced oscillation technique, impulse oscillometry (IO) is a noninvasive, effort-independent method for assessing respiratory mechanics. ${ }^{(9)}$ Previously studied in clinical practice, IO involves the application of pressure pulses of single or multiple frequencies to the airways, allowing measurement of Rrs, respiratory system impedance, and respiratory system reactance (Xrs). ${ }^{(4,10,11)}$

One of the advantages of IO over other methods is that it allows differentiation between central Rrs and peripheral Rrs. ${ }^{(11)}$ In addition, the fact that IO requires no patient effort and minimal patient cooperation makes it easier to perform than spirometry or plethysmography. ${ }^{(12,13)}$

The objective of the present study was to evaluate peripheral Rrs and Xrs by IO in individuals with varying degrees of obesity.

\section{METHODS}

This was an exploratory, comparative observational study conducted between June of 2007 and March of 2010 in the Laboratório de Função Pulmonar of the Hospital das Clínicas of the Universidade Federal de Pernambuco, in the city of Recife, Brazil. The study was approved by the local research ethics committee (Protocol no. 0316.0.172.000-07). All participants gave written informed consent.

We recruited 99 individuals between 18 and 60 years of age, dividing them into four groups by body mass index (BMI): $<30.0 \mathrm{~kg} / \mathrm{m}^{2}$ (control, $\mathrm{n}=31$ ); 30.0-39.9 kg/m² (obesity, $\mathrm{n}=13$ ); 40.0-49.9 kg/m² (severe obesity, $\mathrm{n}=$ 28 ); and $\geq 50.0 \mathrm{~kg} / \mathrm{m}^{2}$ (morbid obesity, $\mathrm{n}=13$ ). Only 12 participants had FVC or $\mathrm{FEV}_{1} / \mathrm{FVC}$ values below $80 \%$ of predicted, 3 of whom were in the control group and 9 of whom were in the severe obesity group.

Individuals with a history of pulmonary disease were excluded, as were those with signs and symptoms of recent pulmonary disease (wheezing on auscultation, cough, or dyspnea), those with a history of smoking, those with chest $\mathrm{X}$-ray changes, those with neurological 
disease, those with musculoskeletal disease, and those who failed to perform forced expiratory maneuvers correctly during spirometry.

Anthropometric data (weight and height) were obtained with the use of an electronic scale (Metalúrgica Arja, São Paulo, Brazil), whereas IO and spirometric parameters were obtained with the MasterScreen IO system (Jäeger, Würzburg, Germany). All tests were performed with the individuals sitting comfortably with both feet flat on the floor, breathing through a plastic mouthpiece, and using a nose clip. The IO system was calibrated daily before data collection, by the variable flow method with a 3-liter syringe (Jäeger).

Spirometry was performed in accordance with the American Thoracic Society guidelines. ${ }^{(14)}$ We evaluated slow vital capacity (SVC), ERV, inspiratory capacity, FVC, $\mathrm{FEV}_{1}, \mathrm{FEV}_{1} / \mathrm{FVC}$, and $\mathrm{FEF}_{25-75 \%}$. For SVC, inspiratory capacity, and $\mathrm{FEV}_{1}$, the highest values obtained from three acceptable maneuvers were selected, whereas $\mathrm{FEF}_{25-75 \%}$ was obtained from the maneuver with the

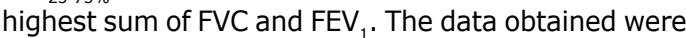
compared with the predicted values for the Brazilian population. ${ }^{(15)}$

During IO, patients were instructed to keep their lips around the mouthpiece and breathe normally for $40 \mathrm{~s}$ while pressing their cheeks together in order to prevent movement and reduce the upper airway shunt effect. The harmonic frequencies of the sound waves ranged from $5 \mathrm{~Hz}$ to $35 \mathrm{~Hz}$, and pressure never exceeded $5.98 \mathrm{cmH}_{2} \mathrm{O}(0.5 \mathrm{kPa})$. We measured total Rrs $(5 \mathrm{~Hz})$, central Rrs $(20 \mathrm{~Hz})$, Xrs $(5 \mathrm{~Hz})$, and resonant frequency (Fres). Peripheral Rrs (also known as frequency dependence of resistance) was calculated as the difference between total Rrs and central Rrs. Low-frequency Xrs is associated with the peripheral airways, which is why Xrs was measured at a frequency of $5 \mathrm{~Hz}$. ${ }^{(16)}$

To ensure reliability, measurements were repeated until consistency was $>0.7$ for a frequency of $5 \mathrm{~Hz}$ and $>0.9$ for a frequency of $20 \mathrm{~Hz}$, a maximum of five maneuvers being performed.(10)

The Kolmogorov-Smirnov test was used in order to assess the distribution of variables. Fisher's exact test was used in order to compare categorical variables. One-way ANOVA and the Kruskal-Wallis test were used in order to compare variables between groups. The chi-square test was used in order to evaluate nominal variables, and Tukey's post hoc test was used in order to determine the pairs of groups that differed from one another. GraphPad Prism, version 4 (GraphPad Software Inc., San Diego, CA, USA), and Microsoft Office Excel 2007 were used.

\section{RESULTS}

A total of 99 individuals participated in the present study. Although all individuals were able to perform IO maneuvers correctly, 14 failed to perform forced expiratory maneuvers correctly during spirometry and were therefore excluded. Of those 14 individuals, 2 were in the control group, 2 were in the obesity group, 5 were in the severe obesity group, and 5 were in the morbid obesity group.

Table 1 presents the general characteristics of the 85 individuals who remained in the study, by group. There were no differences among the groups regarding age. With regard to gender, females predominated in the control, severe obesity, and morbid obesity groups.

Table 2 shows an intergroup comparison of mean spirometric values (in \% of predicted) in the study population. Both FVC and $\mathrm{FEV}_{1}$ were significantly lower in the morbid obesity group than in the control and obesity groups; SVC was significantly lower in the morbid obesity group than in the obesity group; and ERV was significantly lower in the severe obesity and morbid obesity groups than in the control and obesity groups.

Table 3 shows an intergroup comparison of mean IO values in the study population. Total Rrs and peripheral Rrs were highest in the severe obesity and morbid obesity groups. This shows that peripheral Rrs is the major factor responsible for an overall increase in Rrs. In addition, Xrs was lowest in the severe obesity and morbid obesity groups. There was a slight negative association between peripheral Rrs and ERV ( $R=$ $-0.32 ; \mathrm{p}<0.01)$.

\section{DISCUSSION}

Obesity is a major risk factor for pulmonary complications arising from changes in lung volumes

Table 1. General characteristics of the study population $(N=85)$, by group. ${ }^{a}$

\begin{tabular}{|c|c|c|c|c|c|}
\hline \multirow[t]{2}{*}{ Characteristic } & \multicolumn{4}{|c|}{ Group $^{b}$} & \multirow[t]{2}{*}{ p } \\
\hline & $\begin{array}{c}\text { Control } \\
(n=31)\end{array}$ & $\begin{array}{c}\text { Obesity } \\
(n=13)\end{array}$ & $\begin{array}{c}\text { so } \\
(n=28)\end{array}$ & $\begin{array}{c}\text { MO } \\
(n=13)\end{array}$ & \\
\hline \multicolumn{6}{|l|}{ Gender* } \\
\hline Male & $9(29.1)$ & $8(61.5)$ & $4(14.2)$ & $5(38.4)$ & 0.1825 \\
\hline Female & 22 (70.9) & $5(38.5)$ & $24(85.8)$ & $8(61.6)$ & 0.5826 \\
\hline Age, years** & $31.8 \pm 11.3$ & $39.6 \pm 9.2$ & $34.8 \pm 12.4$ & $34.1 \pm 6.9$ & 0.1924 \\
\hline $\mathrm{BMI}, \mathrm{kg} / \mathrm{m}^{2 * *}$ & $24.2 \pm 3.0$ & $32.6 \pm 2.7$ & $45.5 \pm 2.7$ & $56.7 \pm 5.2$ & $<0.0001$ \\
\hline
\end{tabular}

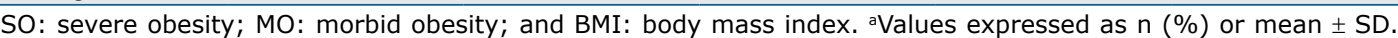
${ }^{b}$ Control group: BMI <30.0 kg/m²; obesity group: BMI $=30.0-39.9 \mathrm{~kg} / \mathrm{m}^{2} ;$ SO group: BMI $=40.0-49.9 \mathrm{~kg} / \mathrm{m}^{2} ;$ and MO group: BMI $\geq 50.0 \mathrm{~kg} / \mathrm{m}^{2}$. ${ }^{*}$ Chi-square test. ${ }^{* *}$ One-way ANOVA and Tukey's post hoc test. 
Table 2. Spirometric variables (in $\%$ of predicted) in the study population $(\mathrm{N}=85){ }^{\text {a }}$

\begin{tabular}{|c|c|c|c|c|}
\hline \multirow[t]{2}{*}{ Variable } & \multicolumn{4}{|c|}{ Group $^{b}$} \\
\hline & $\begin{array}{l}\text { Control } \\
(n=31)\end{array}$ & $\begin{array}{l}\text { Obesity } \\
(n=13)\end{array}$ & $\begin{array}{c}\text { so } \\
(n=28)\end{array}$ & $\begin{array}{c}\text { MO } \\
(n=13)\end{array}$ \\
\hline FVC & $97.6 \pm 15.5$ & $100.6 \pm 12.5$ & $90.6 \pm 12.2$ & $81.9 \pm 14.3^{* \dagger}$ \\
\hline $\mathrm{FEV}_{1}$ & $97.4 \pm 12.1$ & $99.5 \pm 14.9$ & $90.6 \pm 12.6$ & $82.4 \pm 16.6^{* \dagger}$ \\
\hline $\mathrm{FEV}_{1} / \mathrm{FVC}$ & $84.6 \pm 7.4$ & $81.4 \pm 7.9$ & $83.4 \pm 6.2$ & $84.3 \pm 6.7$ \\
\hline $\mathrm{FEF}_{25-75 \%}$ & $98.3 \pm 19.1$ & $106.2 \pm 29.0$ & $95.3 \pm 27.4$ & $83.1 \pm 29.0$ \\
\hline ERV & $121.6 \pm 35.7$ & $111.8 \pm 53.0$ & $73.3 \pm 27.6^{* \dagger}$ & $52.3 \pm 26.2^{* \dagger}$ \\
\hline IC & $96.7 \pm 26.4$ & $114.7 \pm 16.2$ & $110.9 \pm 19.6$ & $106.7 \pm 29.3$ \\
\hline SVC & $100.7 \pm 15.8$ & $104.9 \pm 17.2$ & $97.9 \pm 10.8$ & $88.4 \pm 16.2^{1}$ \\
\hline
\end{tabular}

SO: severe obesity; MO: morbid obesity; ERV: expiratory reserve volume; IC: inspiratory capacity; and SVC: slow

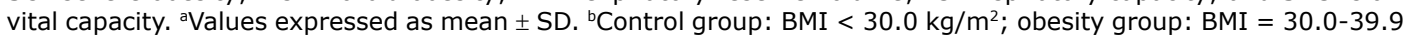
$\mathrm{kg} / \mathrm{m}^{2}$; SO group: BMI $=40.0-49.9 \mathrm{~kg} / \mathrm{m}^{2}$; and MO group: BMI $\geq 50.0 \mathrm{~kg} / \mathrm{m}^{2}$. $* \mathrm{p}<0.01 \mathrm{vs}$. control group. ${ }^{+} \mathrm{p}<$ 0.01 vs. obesity group. " p $<0.05$ vs. obesity group. One-way ANOVA and Tukey's post hoc test.

Table 3. Impulse oscillometry variables in the study population $(\mathrm{N}=85){ }^{\text {a }}$

\begin{tabular}{|c|c|c|c|c|}
\hline \multirow[t]{2}{*}{ Variable } & \multicolumn{4}{|c|}{ Group $^{b}$} \\
\hline & $\begin{array}{l}\text { Control } \\
(n=31)\end{array}$ & $\begin{array}{l}\text { Obesity } \\
\text { (n = 13) }\end{array}$ & $\begin{array}{c}\text { so } \\
(n=28)\end{array}$ & $\begin{array}{c}\text { MO } \\
(n=13)\end{array}$ \\
\hline Total Rrs, $\mathrm{cmH}_{2} \mathrm{O} / \mathrm{L} / \mathrm{s}$ & $4.3 \pm 1.1$ & $4.5 \pm 1.5$ & $5.6 \pm 1.7^{*}$ & $6.0 \pm 1.2^{\dagger}$ \\
\hline Total Rrs, \% of predicted & $130.2 \pm 36.6$ & $136.5 \pm 39.7$ & $163.0 \pm 54.0^{9}$ & $185.6 \pm 46.0^{\dagger * *}$ \\
\hline Central Rrs, $\mathrm{cmH}_{2} \mathrm{O} / \mathrm{L} / \mathrm{s}$ & $3.7 \pm 1.0$ & $3.7 \pm 1.2$ & $4.2 \pm 1.4$ & $4.4 \pm 1.1$ \\
\hline Central Rrs, $\%$ of predicted ${ }^{c}$ & $135.1 \pm 38.2$ & $133.9 \pm 39.7$ & $146.3 \pm 51.7$ & $161.9 \pm 48.0$ \\
\hline Peripheral Rrs, $\mathrm{cmH}_{2} \mathrm{O} / \mathrm{L} / \mathrm{s}$ & $0.5 \pm 0.4$ & $0.7 \pm 0.4$ & $1.4 \pm 0.6^{* \dagger}$ & $1.6 \pm 0.4^{* \dagger}$ \\
\hline Fres, $\mathrm{Hz}$ & $13.5 \pm 3.6$ & $16.2 \pm 2.6$ & $19.2 \pm 3.1^{* . * *}$ & $20.4 \pm 3.9^{* . * *}$ \\
\hline $\mathrm{Xrs}, \mathrm{cmH}_{2} \mathrm{O} / \mathrm{L} / \mathrm{s}$ & $-1.3 \pm 0.4$ & $-1.6 \pm 0.9$ & $-2.0 \pm 0.8^{n}$ & $-2.1 \pm 0.91$ \\
\hline
\end{tabular}

SO: severe obesity; MO: morbid obesity; Rrs: respiratory system resistance; Fres: resonant frequency; and Xrs:

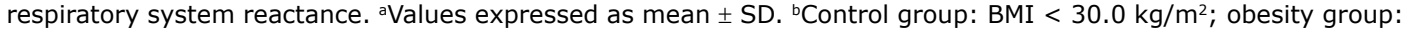
BMI $=30.0-39.9 \mathrm{~kg} / \mathrm{m}^{2}$; SO group: BMI $=40.0-49.9 \mathrm{~kg} / \mathrm{m}^{2} ;$ and MO group: BMI $\geq 50.0 \mathrm{~kg} / \mathrm{m}^{2}$. ${ }^{\circ}$ Calculated on the basis of Pelosi et al. ${ }^{(20) * p}<0.01$ vs. control group. ${ }^{\dagger} p<0.01$ vs. obesity group. ${ }^{1} p<0.05$ vs. control group. $* * p<0.05$ vs. obesity group. One-way ANOVA and Tukey's post hoc test.

and peripheral Rrs and can lead to increased work of breathing and reduced gas exchange. ${ }^{(17-19)}$

The results of the present study show reduced SVC and $\mathrm{FEV}_{1}$ in severely obese or morbidly obese individuals (Table 2), as reported elsewhere. ${ }^{(20-23)}$ In addition, analysis of IO parameters revealed a strong association of the degree of obesity with increased peripheral Rrs and reduced Xrs (Table 3 ).

Fat deposition in the neck, thorax, and abdomen can lead to reduced lung volumes, resulting in reduced elastic recoil pressure of the lung and of the walls of the smaller bronchi, as well as in reduced airway caliber. In addition, the mechanical disadvantage imposed on the diaphragm by an increase in abdominal pressure leads to reduced ERV. The aforementioned factors, together with extrinsic airway compression, result in expiratory airflow limitation in obese individuals. ${ }^{(3)}$

In obese individuals, functional residual capacity is more markedly reduced than is residual volume; consequently, there is a marked reduction in ERV. Therefore, in obese individuals, tidal breathing occurs at low lung volumes. Under such conditions, some airways tend to narrow or even close during exhalation. (24) The association between IO variables and plethysmography variables should be evaluated in order to confirm the relationship between reduced lung volume and airway narrowing.

One advantage of IO over other methods for evaluating respiratory mechanics, such as spirometry and whole-body plethysmography, is that IO does not require forced expiratory maneuvers (which can affect bronchial tone), therefore requiring minimal patient cooperation. ${ }^{(13)}$ In this regard, we were able to measure IO parameters correctly in 14 obese patients who failed to perform forced expiratory maneuvers correctly during spirometry.

Zerah et al. ${ }^{(5)}$ used plethysmography in order to study lung volumes and respiratory mechanics in 46 individuals with no history of lung disease and found increased airway resistance and reduced lung volumes in those whose BMI was $\geq 30 \mathrm{~kg} / \mathrm{m}^{2}$. Oliveira et al. ${ }^{(4)}$ used IO and found increased airway resistance in 25 obese individuals who were compared with 25 non-obese individuals. However, neither group of authors stratified patients by BMI. This was done in the present study, which showed that the aforementioned changes occur predominantly in severely obese or morbidly obese individuals, i.e., those whose BMI is $\geq 40 \mathrm{~kg} / \mathrm{m}^{2}$. In addition, we differentiated between central Rrs and peripheral Rrs, which clearly showed the role that the small airways play in airflow limitation in such patients, as demonstrated by increased Fres and peripheral Rrs. 
Both Fres and peripheral Rrs as measured by IO, which are considered to be small airway markers, ${ }^{(25-27)}$ can detect increased peripheral Rrs. ${ }^{(16)}$ Friedman et al. (28) evaluated IO data from residents and area workers who inhaled dust and fumes from the World Trade Center disaster and found increased total Rrs and increased peripheral Rrs, which were associated with increased exposure to dust and fumes, as well as with lower respiratory symptoms.

In patients with mild to moderate asthma, Yamaguchi et al. ${ }^{(29)}$ found reduced peripheral Rrs after 12 weeks of treatment with inhaled hydrofluoroalkane-134a beclomethasone dipropionate, which has ultrafine particles; however, no changes were observed in $\mathrm{FEF}_{25-75 \%}$. These findings suggest that IO is more sensitive to measure the response to asthma and COPD treatment than are other methods. ${ }^{(30)}$

A complex concept, Xrs incorporates lung elastic recoil properties. Low-frequency Xrs has been correlated with peripheral airway obstruction. At low frequencies, there is passive lung distension, increased lung compliance, reduced elastic recoil pressure, and reduced Xrs. ${ }^{(13)}$ $\mathrm{Xrs}$ at $5 \mathrm{~Hz}$ expresses $\mathrm{Xrs}$ as a whole, being reduced in patients with restrictive lung disease and in those with chest wall disease. ${ }^{(13,16)}$ Our comparative analysis revealed a significant reduction in Xrs in severely obese and morbidly obese individuals. This finding reflects the association between obesity and reduced Xrs, given that none of the study participants had abnormal chest X-ray findings or a history of collagen disease.

Our results show that individuals with a BMI $\geq 40$ $\mathrm{kg} / \mathrm{m}^{2}$ can have normal spirometry results despite significant changes in respiratory mechanics, which are detected by IO. Reduced lung volume resulting from the interdependence of tissue structures reduces small airway diameter, increasing small airway resistance. Future studies will soon be able to show real, volume-corrected obstruction, combining IO data with residual volume and functional residual capacity as determined by plethysmography.

In this context, the clinical relevance of IO is evident, given that it is an accurate, noninvasive method for evaluating changes in respiratory mechanics (Rrs and $\mathrm{Xrs}$ ) in the early stages of disease. The findings of the present study show the importance of drawing treatment plans aimed at reducing airway resistance and, consequently, improving lung function in obese individuals, especially those with respiratory symptoms. In addition, IO is an alternative method for evaluating patients who are unable to perform the required respiratory maneuvers for spirometry and plethysmography.

\section{REFERENCES}

World Health Organization [homepage on the Internet]. Geneva: WHO; c2015 [updated 2015 Jan; cited 2015 Apr 21]. Obesity and overweight. Fact Sheet No 311; [about 5 screens]. Available from: http://www.who.int/mediacentre/factsheets/fs311/en/index.html

2. Guh DP, Zhang W, Bansback N, Amarsi Z, Birmingham $C L$, Anis $A H$. The incidence of co-morbidities related to obesity and overweight: a systematic review and meta-analysis. BMC Public Health. 2009;9:88. http://dx.doi.org/10.1186/1471-2458-9-88

3. Littleton SW. Impact of obesity on respiratory function. Respirology. 2012;17 (1):43-9. http://dx.doi.org/10.1111/j.1440-1843.2011.02096.x

4. Oliveira FB, Aguiar LG, Bouskela E, Jansen JM, Melo PL. Análise do efeito da obesidade sobre as propriedades resistivas e elásticas do sistema respiratório por oscilações forçadas. Pulmão RJ. 2006;15(4):219-23

5. Zerah F, Harf A, Perlemuter L, Lorino H, Lorino AM, Atlan G. Effects of obesity on respiratory resistance. Chest. 1993:103(5):1470-6. http://dx.doi.org/10.1378/chest.103.5.1470

6. McClean KM, Kee F, Young IS, Elborn JS. Obesity and the lung: 1. Epidemiology. Thorax. 2008;63(7):649-54. http://dx.doi.org/10.1136/ thx.2007.086801

7. King GG, Brown NJ, Diba C, Thorpe CW, Mu-oz P, Marks GB, et al. The effects of body weight on airway calibre. Eur Respir J. 2005;25(5):896-901. http://dx.doi.org/10.1183/09031936.05.001045 04

8. Sin DD, Sutherland ER. Obesity and the lung: 4. Obesity and asthma. Thorax. 2008;63(11):1018-23. http://dx.doi.org/10.1136/ thx.2007.086819

9. DUBOIS AB, BOTELHO SY, COMROE JH Jr. A new method for measuring airway resistance in man using a body plethysmograph: values in normal subjects and in patients with respiratory disease. $J$ Clin Invest. 1956;35(3):327-35. http://dx.doi.org/10.1172/JCI103282

10. Melo PL, Werneck MM, Giannella-Neto A. Analysis of the ventilatory mechanics by forced oscillations technique: main concepts and clinical applications [Article in Portuguese]. J Pneumol. 2000;26(4):194-206

11. Hellinckx J, Cauberghs M, De Boeck K, Demedts M. Evaluation of impulse oscillation system: comparison with forced oscillation technique and body plethysmography. Eur Respir J. 2001;18(3):564-
70. http://dx.doi.org/10.1183/09031936.01.00046401

12. Chlif M, Keochkerian D, Choquet D, Vaidie A, Ahmaidi S. Effects of obesity on breathing pattern, ventilatory neural drive and mechanics. Respir Physiol Neurobiol. 2009;168(3):198-202. http://dx.doi. org/10.1016/j.resp.2009.06.012

13. Smith HJ, Reinhold P, Goldman MD. Forced oscillation technique and impulse oscillometry. Eur Respir Mon. 2005;31:72-105. http:// dx.doi.org/10.1183/1025448x.00031005

14. Miller MR, Hankinson J, Brusasco V, Burgos F, Casaburi R, Coates A et al. Standardisation of spirometry. Eur Respir J. 2005;26(2):319-38. http://dx.doi.org/10.1183/09031936.05.00034805

15. Pereira CA, Barreto SP, Simões JG, Pereira FW, Gerstler JG, Nakatani J. Reference values for spirometry in Brazilian adults [Article in Portuguese]. J Pneumol. 1992;18(1):10-22.

16. Oostveen E, MacLeod D, Lorino H, Farré R, Hantos Z, Desager K, et al. The forced oscillation technique in clinical practice: methodology, recommendations and future developments. Eur Respir J 2003;22(6):1026-41. http://dx.doi.org/10.1183/09031936.03.000894 03

17. Watson RA, Pride NB. Postural changes in lung volumes and respiratory resistance in subjects with obesity. J Appl Physiol (1985). 2005:98(2):512-7.

18. Koenig SM. Pulmonary complications of obesity. Am J Med Sci. 2001;321(4):249-79. http://dx.doi.org/10.1097/00000441-20010400000006

19. Jubber AS. Respiratory complications of obesity. Int J Clin Pract. 2004;58(6):573-80. http://dx.doi.org/10.1111/j.1368 5031.2004.00166.x

20. Pelosi $P$, Croci M, Ravagnan I, Cerisara M, Vicardi $P$, Lissoni $A$, et al. Respiratory system mechanics in sedated, paralyzed, morbidly obese patients. J Appl Physiol (1985). 1997;82(3):811-8.

21. Jones RL, Nzekwu MM. The effects of body mass index on lung volumes. Chest. 2006;130(3):827-33. http://dx.doi.org/10.1378/ chest.130.3.827

22. Ochs-Balcom HM, Grant BJ, Muti P, Sempos CT, Freudenheim $\mathrm{JL}$, Trevisan $\mathrm{M}$, et al. Pulmonary function and abdominal adiposity in the general population. Chest. 2006;129(4):853-62. http://dx.doi. org/10.1378/chest.129.4.853 
23. Ladosky W, Botelho MA, Albuquerque JP Jr. Chest mechanics in morbidly obese non-hypoventilated patients. Respir Med 2001;95(4):281-6. http://dx.doi.org/10.1053/rmed.2001.1035

24. Pellegrino R, Gobbi A, Antonelli A Torchio R, Gulotta C Pellegrino GM, et al. Ventilation heterogeneity in obesity. J App Physiol (1985). 2014;116(9):1175-81. http://dx.doi.org/10.1152/ japplphysiol.01339.2013

25. Goldman MD. Clinical application of forced oscillation. Pulm Pharmacol Ther. 2001;14(5):341-50. http://dx.doi.org/10.1006/ pupt.2001.0310

26. Nieto A, Pamies R, Oliver F, Medina A, Caballero L, Mazon A Montelukast improves pulmonary function measured by impulse oscillometry in children with asthma (Mio study). Respir Med. 2006;100(7):1180-5. http://dx.doi.org/10.1016/j.rmed.2005.10.025

27. Williamson PA, Clearie K, Menzies D, Vaidyanathan S, Lipworth BJ. Assessment of small-airways disease using alveolar nitric oxide and impulse oscillometry in asthma and COPD. Lung. 2011;189(2):121-9. http://dx.doi.org/10.1007/s00408-010-9275-y

28. Friedman SM, Maslow CB, Reibman J, Pillai PS, Goldring RM, Farfe MR, et al. Case-control study of lung function in World Trade Center Health Registry area residents and workers. Am J Respir Crit Care Med. 2011;184(5):582-9. http://dx.doi.org/10.1164/rccm.201011 19090C

29. Yamaguchi M, Niimi A, Ueda T, Takemura M, Matsuoka $H$, Jinnai M, et al. Effect of inhaled corticosteroids on small airways in asthma: investigation using impulse oscillometry. Pulm Pharmacol Ther. 2009;22(4):326-32. http://dx.doi.org/10.1016/j.pupt.2009.01.005

30. Abe T, Setoguchi Y, Kono Y, Togashi Y, Sugiyama S, Tanakadate $M$, et al. Effects of inhaled tiotropium plus transdermal tulobutero versus tiotropium alone on impulse oscillation system (IOS)assessed measures of peripheral airway resistance and reactance, lung function and quality of life in patients with COPD: a randomized crossover study. Pulm Pharmacol Ther. 2011;24(5):617-24. http:// dx.doi.org/10.1016/j.pupt.2011.06.002 